\title{
Quantitative sampling of benthic organisms by diving on the Swedish west coast
}

\author{
Göran Michanek \\ Marine Botanical Institute, Botanical Garden, Göteborg, Sweden
}

KURZFASSUNG: Quantitative Erfassung benthischer Organismen mit Hilfe der Tauchtechnik an der schwedischen Westküste. Durch GIsLÉN (1929-1930) wurde eine umfassende ökologische Untersuchung der Epibiosen im Gullmar-Fjord an der schwedischen Skagerrak-Küste vorgenommen. Anhand zahlreicher Probenentnahmen durch einen Taucher wurde der Organismenbestand qualitativ und quantitativ untersucht. Im gleichen Gebiet wurden 40 Jahre später Vergleichsuntersuchungen durchgeführt, um Veränderungen in der Zusammensetzung und Verteilung der Biozönosen zu ermitteln. Parallele und divergierende Befunde hinsichtlich der Artenzusammensetzung der benthonischen Lebensgemeinschaften werden gegenübergestellt und diskutiert.

\section{INTRODUCTION}

To scrape off all organisms within chosen test squares and to scrutinize the samples would seem a reasonable way to collect material for describing submarine benthic biocoenoses, their constancy and variation. But is it sufficient for the assessment of changes in the fauna and flora of a region to compare such samples taken at different times?

Looking for an answer to this question, an opportunity for a critical test arose in the Gullmar Fjord on the west coast of Sweden. Forty years ago the first comprehensive investigation on its submarine biocoenoses was started by GrsLén (1929-1930). His results appeared in a now classical work "Epibioses of the Gullmar Fjord". During a period of four years GisLén analysed what he called epibioses at 35 stations in outer and inner parts of the fjord, in the archipelago off the mouth of the fjord and in adjacent water systems. At each station 1 to 10 samples were taken from different depths. The greatest depth sampled was $33.6 \mathrm{~m}$. In all, 190 scraped squares were registered; in addition, at 43 points - preferably near the surface - associations were described in a simpler way.

\section{PROBLEMS AND RESUITS}

Would it be advisable to repeat the investigation of GISLÉN using identical methods, and if so, how should this be done to give comparable results? Or should such ecological work today be based on a different approach? 
My first intention was to undertake this task on the basis of an approach completely unbiased by GisLÉN's previous results. I noted locality and depths, went down

Table 1

Station 3d Smedjan, outer archipelago, $0.8 \mathrm{~m}$ - a comparison of my findings (August 5, 1966) and those of GISLÉN (August 5, 1926); wet weight in g per quadrat

August 5, 1966

Plants:

Polysiphonia urceolata

Cladophora albida

Chordaria flagelliformis

A n im a ls :

Mytilus edulis

Littorina littorea

Saxicava rugosa

Mytilis-dominated biotope
August 5, 1926

Plants:

Corallina officinalis

Animals :

Purpurea lapillus

Saxicava rugosa

Littorina littorea

Nereis pelagica

Littorina obtusata

10

+ Metridium dianthus

According to GIsLÉN : Corallina association

Table 2

Abundant species in test areas $\left(1 / 4 \mathrm{~m}^{2}\right)$; given are wet weights in $\mathrm{g}$;

Station $14 \mathrm{f}, 11 \mathrm{~m}$. W. Hågarnskären, outer part of the fjord. A comparison of three squares from 1966 with that of GISLÉN from 1926

(a) August 3, 1966

A 1 g a e :

Corallina of ficinalis

Ceramium rubrum

Furcellaria fastigiata

Lomentaria clavellosa

Chondrus crispus

Phyllophora brodiaei

Animals:

Pomatoceros triqueter

Asterias rubens

Ascidiella scabra-Corella

Modiolaria marmorata

(c) August 13, 1966

Alga e :

Chondrus crispus

Delesseria sangtuinea

Lomentaria clavellosa

Phyllophora membranifolia

Furcellaria fastigiata

Corallina officinalis

Animals:

Pomatoceros triqueter

Modiolaria marmorata

Ascidiella scabra

29

Kirchenpaueria pinnata

Balanus balanus (b) August 13, $1966\left(80^{\circ}\right)$

A lga e:

Lomentaria clavellosa

Furcellaria fastigiata

Pbyllophora membranifolia

Desmarestia aculeata

Delesseria sanguinea

Animals:

Ascidiella scabra

Pomatoceros triqueter

(d) August 3, 1926 (GrsLÉN)

A lga e :

Furcellaria fastigiata

Phyllophora brodiaei

Brongniartella byssoides

Stilophora rbizoides

Rhodomela virgata

Delesseria sanguinea

Laminaria saccharina, fragments

An imals:

Ascidiella aspersa

Styela rustica

Alcyonium digitatum

Balanus balanus

+ Anomia pat.

Association according to GISLÉN "Mottled" 
and chose a test square (quadrat) that appeared to be representative; I did this without looking into the key about the type of community provided by GISLÉN.

This "unbiased" method gave only one information, a rather expected one, namely, that at a certain place and depth there are different communities. One can hit upon something related to the old quadrats but one is just as likely to find something else. An example is shown in Table 1.

Another way to work would be to take parallel samples and then see if the 40 year old registrations fall within or outside the present variation (Tables 2 and 3 ).

\section{Table 3}

Abundant species in test areas $\left(1 / 4 \mathrm{~m}^{2}\right)$; given are wet weights in $\mathrm{g}$. See text to Table 2; depth: $16 \mathrm{~m}$

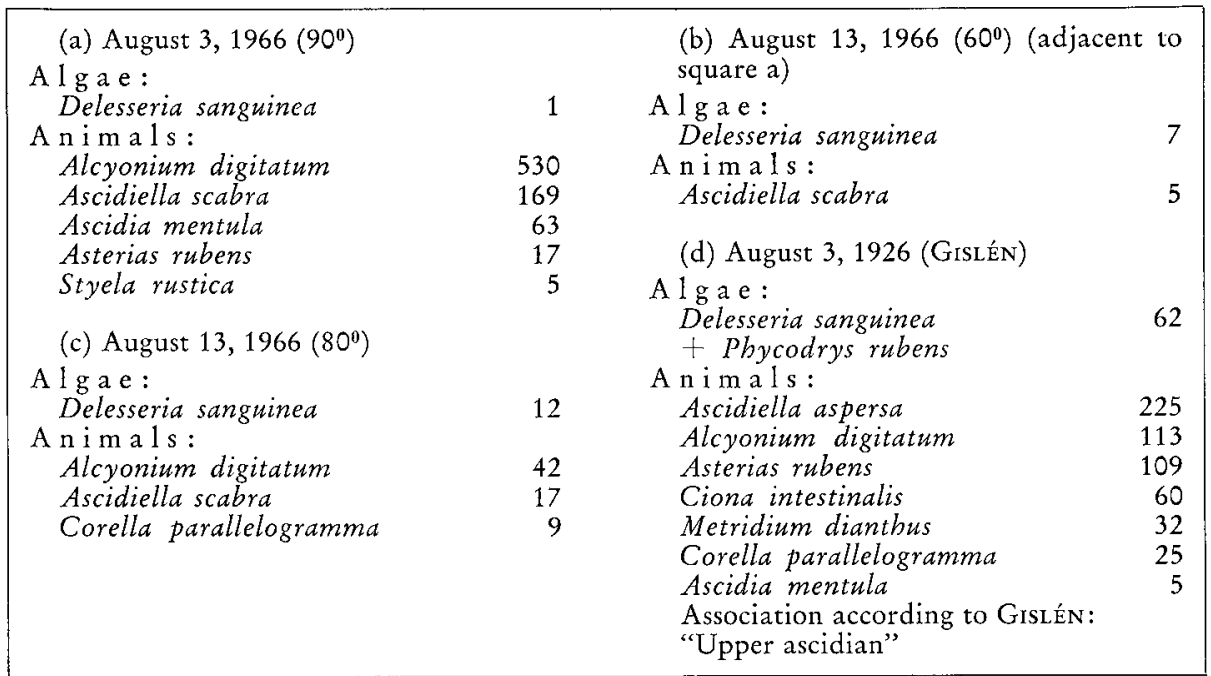

The results show that three test squares sampled at the same time and under the same conditions can be so different that we cannot expect coincidence between two individual samples taken in 1926 or 1966 respectively. Still less is it permitted to assume that the differences noted are significant for changes which may have occurred during the time which has passed between 1926 and 1966.

Adjacent test squares with different slopes show differences which may be as pronounced as those between samples from different depths. Here Scuba-diving is a tool that can give us rich and exact information. Another important aspect which cannot be approached by employing dredges and bottom samplers, is the difference between apparently comparable localities such as are free from sediments and those covered by sedimented particles (detritus, mud, dead organisms).

A locality heavily covered by soft sediments is, for example, Station $10 \mathrm{i}, 17 \mathrm{~m}$, at the border between fjord-mouth and archipelago. Here the faintest movements stir up impenetrable sediment clouds. The bottom as well as the frame used became invisible when collecting started. The most abundant species were Furcellaria, Pbyllo- 
pbora, Chondrus and Corallina. These species had replaced Delesseria, Brongniartella and Rbodomela virgata which grew at similar, but "dust-free" places, i.e. at Station $14 \mathrm{~g}, 16 \mathrm{~m}$. At the sediment-rich station echinoderms were very abundant; on the $30^{\circ}$ slope of the rock the encrusting alga Crnoria was totally lacking, as were Balanus and Pomatoceros. These species were covering the steeper rock at Station $14 \mathrm{~g}$. This difference between clean and dusty slopes may be typical of coasts such as the Swedish one where the tide amplitude amounts to some $30 \mathrm{~cm}$.

Table 4

Wet weight of plants and animals in $\mathrm{g}$ per test quadrat. A comparison of collectings from 1926 and from parallels in 1966

\begin{tabular}{|c|c|c|c|c|c|c|c|c|c|c|c|}
\hline \multicolumn{2}{|c|}{ Station } & \multicolumn{4}{|c|}{ Epibioses 1926} & \multicolumn{4}{|c|}{ Revisit 1966} & \multicolumn{2}{|c|}{$\begin{array}{l}\text { Difference } \\
1966-1926\end{array}$} \\
\hline $\mathrm{Nr}$. & Depth & $\begin{array}{l}\text { Wet } \\
\text { plants }\end{array}$ & $\begin{array}{l}\text { reight } \\
\text { ani- } \\
\text { mals }\end{array}$ & $\begin{array}{l}\text { Total } \\
\text { weight } \\
\text { of } \\
1 / 4 \mathrm{~m}^{2}\end{array}$ & $\begin{array}{l}\text { Plant } \\
\text { per- } \\
\text { cent- } \\
\text { age }\end{array}$ & \multicolumn{2}{|c|}{ Wet weight } & $\begin{array}{c}\text { Total } \\
\text { weight } \\
\text { of } \\
1 / 4 \mathrm{~m}^{2}\end{array}$ & $\begin{array}{c}\text { Plant } \\
\text { per- } \\
\text { cent- } \\
\text { age }\end{array}$ & $\begin{array}{c}\text { Total } \\
1966 \\
\text {-total } \\
1926\end{array}$ & $\begin{array}{c}\text { Plant } \\
0 \% \\
1966- \\
1926\end{array}$ \\
\hline $3 d$ & 0.8 & 750 & 88 & 838 & 89.5 & 243 & 2595 & 2838 & 8.5 & +2000 & -81 \\
\hline $3 f$ & 5 & 2541 & 197 & 2738 & 92.8 & 2007 & 87 & 2094 & 95.9 & -644 & 3 \\
\hline $3 \mathrm{~g}$ & 6.5 & 555 & 32 & 587 & 94.6 & 2047 & 295 & 2342 & 87.4 & +1755 & -7 \\
\hline $10 \mathrm{i}$ & 17 & 67 & 1212 & 1279 & 5.2 & 109 & 621 & 730 & 14.9 & -549 & 10 \\
\hline $14 \mathrm{f} 3.8$ & 8. 11 & 490 & 122 & 612 & 80.1 & 97 & 185 & 282 & 34.4 & -330 & -46 \\
\hline $14 \mathrm{f} 80^{\circ}$ & $\begin{array}{l}0 \\
0\end{array}$ & $»$ & ” & $"$ & ” & 43 & 53 & 96 & 44.8 & -516 & -35 \\
\hline $14 f \quad 60^{\circ}$ & $\begin{array}{ll}0 & 11\end{array}$ & $"$ & & $"$ & 7 & 114 & 107 & 221 & 51.6 & -391 & -28 \\
\hline $14 \mathrm{~g} 90^{\circ}$ & 016 & 62 & 577 & 639 & 9.7 & 1 & 803 & 804 & 0.1 & +165 & -10 \\
\hline $14 \mathrm{~g} 60^{\circ}$ & 016 & " & " & " & $"$ & 12 & 12 & 24 & 50 & -615 & 40 \\
\hline $14 \mathrm{~g} 80^{\circ}$ & 016 & $"$ & ” & " & , & 14 & 79 & 93 & 15.1 & -546 & 5 \\
\hline $24 a$ & 0.25 & 2925 & 19 & 2944 & 99.4 & 1471 & 160 & 1631 & 90 & -1313 & -9 \\
\hline & 0.4 & - & - & - & - & 75 & 10 & 85 & 86.3 & & \\
\hline $24 b$ & 1.5 & 1186 & 318 & 1503 & 78.9 & 332 & 198 & 530 & 62.7 & -973 & -16 \\
\hline
\end{tabular}

There seems to be a discrepancy on two points. GrsLÉn records 43 findings of 27 species of algae, while I have noted 118 findings of 52 species from the corresponding squares. The difference depends mainly on the fact that GisLén has noted only bigger specimens (and a zooendophyte) while I have taken interest also in smaller species. Further, the weight of the collected material is definitely lower in most of my samples than in GISLÉn's.

The explanation in this last point could be, that by false ambitions the diver appointed by GISLÉN has yielded to the temptation to pick up some nice specimens from the immediate surroundings of the square or at least to put the frame over some big and beautiful specimens. Other explanations could be either diminished light today, or the fact that the winter before my collecting had included an unusually long period of ice-cover. On the other hand the summer afterwards was warm. Own observations, however, point to an important fact: pressure can produce a slight depth intoxication making the diver more generous than desirable. We must consider such psychological factors as well as hydrographical observations.

To be able to demonstrate slight changes or differences it is necessary to study as 
many test squares as possible. Only in this way may we try to allow for the mosaic patterns of many rocky sea bottom communities.

\section{SUMMARY}

1. In the Gullmar Fjord (west coast of Sweden) bottom test squares had been sampled 40 years ago by GrsLÉn (1929-30). Studying the same squares in 1966, using skin diving equipment, has led to different results in regard to the fauna and flora found.

2. If the old records are compared with a number of new ones, obtained from the same place and depth, the degree of variation encountered in the new samples may serve as indicator for assessing true differences between biocoenoses in 1926 and 1966.

3. Differences between adjacent test squares depend mainly on the slope of the rock. Other factors which may affect the community structure over short distances are direction and light.

4. Certain organisms settle on bottom areas where calm waters allow sedimentation.

5. Increasing pollution demands sufficient and extensive registration of the actual situation in order to allow for comparisons. For this purpose even a lot of scattered observations can never be equal to numerous data from each of a few chosen places, which are representing the main trends in the sea bottom mosaic.

\section{ACKNOWLEDGEMENTS}

Financial contribution has been received from the P. A. LARssons fund. Dr. B. SWEDMARK at Kristineberg's Zoological Station and Dr. J. SöDerström on his "Velella" have placed boats and other aid at my disposal. Co-diver M. Amundin gave valuable assistance.

\section{LITERATURE CITED}

GisLÉn, T., 1929/30. Epibioses of the Gullmar Fjord. Pt 1. Geomorphology and hydrography. 2. Marine sociology. (Kristinebergs Zoologiska Station, 1877-1927.) SkrSer. K. svenska VetenskAkad. 1929 (3), 1-123; 1930 (4), 1-380.

\section{Discussion following the paper by MICHANEK}

Svenden: How close did you get to GrsLén's localities?

MichaneK: GisléN gives his localities rather carefully, e. g. Station 10i, Spättan shoal east, $17 \mathrm{~m}$. East of this shoal this depth can be found only at a certain distance. Normally I should not miss the point by many meters, say not more than by $10 \mathrm{~m}$.

SVENDSEN: Wet weight of algae is difficult to define. How did you proceed in weighing?

Michanek: According to Gislén the coarser algae were weighed after the water was allowed to run away and as much as possible shaken off. The tender ones were pressed between the fingers until no more water dropped from them. 